\title{
Analysis of the Baiu Precipitation and Associated Circulations Simulated by the MIROC Coupled Climate System Model
}

\author{
Danqing HUANG \\ School of Atmospheric Sciences, Nanjing University, Nanjing, China \\ Key Laboratory of Meteorological Disaster of Ministry of Education, Nanjing University of Information Science and \\ Technology, China
}

Masaaki TAKAHASHI

Atmosphere and Ocean Research Institute, the University of Tokyo, Tokyo, Japan

and

Yaocun ZHANG

School of Atmospheric Sciences, Nanjing University, Nanjing, China

(Manuscript received 6 May 2010, in final form 30 August 2011)

\begin{abstract}
The major features of Baiu simulated by the climate model (MIROC_Hires) are examined by analyzing the differences between simulations and the National Centers for Environmental Prediction/National Center for Atmospheric Research (NCEP/NCAR) reanalysis data during 1981-2000, focusing on the evaluation of the model performances in reproducing the Baiu precipitation climatology as well as the associated 3-dimensional circulation systems, the relationship with Indian Summer Monsoon (ISM) and the configuration of upper and lower level jets. The results show that the model can reproduce heavy precipitation centers over the Yangtze-Huai River Basin during the Baiu period. The horizontal and vertical structures of the circulation systems during the Baiu period are also well simulated, such as an intensive meridional gradient of moisture and it's equivalent potential temperature, the strong low-level southwesterly flow in the lower troposphere over East China, the location of the westerly jet in the upper troposphere, the strong ascending motion over heavy rainfall area (HRA) and compensatory descending motion over the northern and southern sides of HRA. However, obvious discrepancies occur in the overestimated precipitation over southeastern China during the Baiu period. In addition, our study suggests that the biases of the ISM and the configuration of upper and lower level jet results in deficiencies in the evolution of Baiu. The simulated onset of ISM is one pentad later than the reanalysis data, while the onset day of simulated Baiu is one pentad later than the reanalysis data, as well. The simulation showed southward shifting of the upper level jet and the stronger, lower level jet. These location and intensity biases essentially favor excess precipitation in southeastern China. Therefore, it is necessary for the coupled model to improve the configuration of upper and lower level jets in simulating the Baiu.
\end{abstract}

Corresponding author: Danqing Huang, School of Atmospheric Sciences, Nanjing University 22\#, Hankou Road, Nanjing, Jiangsu, China.

E-mail: huangdq@nju.edu.cn

(C)2011, Meteorological Society of Japan

\section{Introduction}

China is greatly affected by summer monsoons and their associated rainfall. A notable example of the sever- 
ity and duration of rainfall is called Meiyu in China, Baiu in Japan and Changma in Korea (hereafter referred to as the Baiu). This rain concentration is in a nearly east-west-elongated rainbelt during June and July, which stretches for many thousands of kilometers, affecting China, Japan, Korea, and the surrounding seas. During Baiu season, the Yangtze-Huai River basin (YHRB, $110^{\circ} \mathrm{E}-122^{\circ} \mathrm{E}, 28^{\circ} \mathrm{N}-34^{\circ} \mathrm{N}$ ) is vulnerable to floods and droughts due to the relative concentration and severity of the rainfall (Chen and Chang 1980; Tao and Chen 1987; Lau et al. 1988; Ding 1992). Thus, the Baiu plays an important role in the East Asia climate variation. It is necessary to study the Baiu systems for disaster prevention in East Asia.

During the Baiu period, several significant features within large-scale circulations can be found. In the upper-troposphere, the position and strength of the subtropical westerly jet over East China place it around $37^{\circ} \mathrm{N}$ and $30 \mathrm{~m} \mathrm{~s}^{-1}$, respectively. The intensity of the westerly jet over the Asian continent weakens and the core of the westerly jet over the western Pacific splits up and intensity reduces, eventually disappearing after the end of Baiu (Du et al. 2008). In the mid-troposphere, the westward extension of the western Pacific subtropical high (WPSH) is an important feature. The WPSH ridge stays steady at $20^{\circ} \mathrm{N}-25^{\circ} \mathrm{N}$ (Ding et al. 2007). At $850 \mathrm{hPa}$, warm and moist southwest monsoon airflows, coming from the Indo-China Peninsula, the South China Sea, and the western Pacific Ocean, are mainly over East China (Huang et al. 1998; Zhou and Yu 2005). Moreover, the strong meridional gradients of moisture and the equivalent potential temperature $\left(\theta_{\mathrm{e}}\right)$ are found over YHRB. In all, the Baiu is generally characterized by a low-level jet stream, strong meridional gradients of moisture and $\theta_{\mathrm{e}}$, and moist neutral stratification (Matsumoto et al. 1971; Ninomiya 1984). Thus, the Baiu is closely related with the monsoon trough, the low level jet, the upper level jet, the WPSH, strong meridional gradients of moisture and other large-scale atmosphere circulations.

It is well known that climate models have been powerful tools in studies on past, present and future climate change. A few reports indicate that simulating the Baiu is difficult in an Atmospheric General Circulation Model (AGCM) with low resolution (T42L21; the maximum zonal wave-number is 42 in triangular wave truncation, and the number of vertical levels are 21) (Sugi et al. 1995). Sperber et al. (1994) compared the ability of the European Centre for Medium-Range Weather Forecasts (ECMWF) model to simulate the Indian and East Asian monsoons at four different horizontal resolutions: T21, T42, T63, and T106. The results indicate
T106 best captures both the spatial and temporal characteristics of East Asian monsoons when compared with the lower resolution models. Based on the higher resolution models, Kawatani and Takahashi (2003) showed that a T106L20 model can simulate Baiu precipitation over Japan in certain periods. Min and Juhn (2010) indicated the higher resolution model (T106) effectively simulates the monthly precipitation pattern over wide areas across the East Asian region including the monsoonal rain band, although it shows a stronger rain band than observations. Thus, the higher resolution models have the ability to identify Baiu precipitation.

In most previous studies, the distribution of simulated Baiu precipitation has been discussed for June or July (based on monthly data) across wide areas in the East Asia region without focus on the 3-dimention circulations (Kar et al. 1996; Kawatani and Takahashi 2003; Li et al. 2008; Ninomiya et al. 2008; Zhou et al. 2008; Ninomiya 2009; Min and Juhn 2010). In general, Baiu mostly occurs from mid-June to midJuly, but with large interannual variability (Hu and Ding 2010), e.g.,"Early Baiu" and "Second Baiu". Kitoh and Uchiyama (2006) defined the onset and withdrawal dates of the summer rainy season using normalized pentad precipitation without considering the associated circulations. However, it is well known that during different periods of Baiu, the features of corresponding circulations are significantly different (Zhu et al. 2000). An accurate reproduction of large-scale circulation systems is important for the simulation of Baiu precipitation. Furthermore, a few numerical experiment studies indicate that whether the simulated Baiu precipitation and its associated circulation are reasonable or not will directly affect the precipitation simulation in the East Asian monsoon region ( $\mathrm{Li}$ et al. 2008; Zhuo et al. 2010). Because most of previous studies discussed the reproducibility of Baiu using monthly and seasonal average data, the simulated Baiu period was not fully compared with observations. Therefore, identifying the exact Baiu period is necessary before evaluating the model ability of Baiu systems. The simulated Baiu period, as well as 3-dimensional circulation fields, should be verified against observations with time scales shorter than monthly and seasonal.

A large number of coordinated experiments using the new generation of coupled climate models have been conducted for the Intergovernmental Panel on Climate Change (IPCC) Fourth Assessment Report (AR4) (Meehl et al. 2004; Meehl et al. 2005). Concerning these model outputs, great effort has been devoted to evaluating the model performance in order to improve model ability (Zhou and Yu 2006; Guo et al. 2008; Zhou 

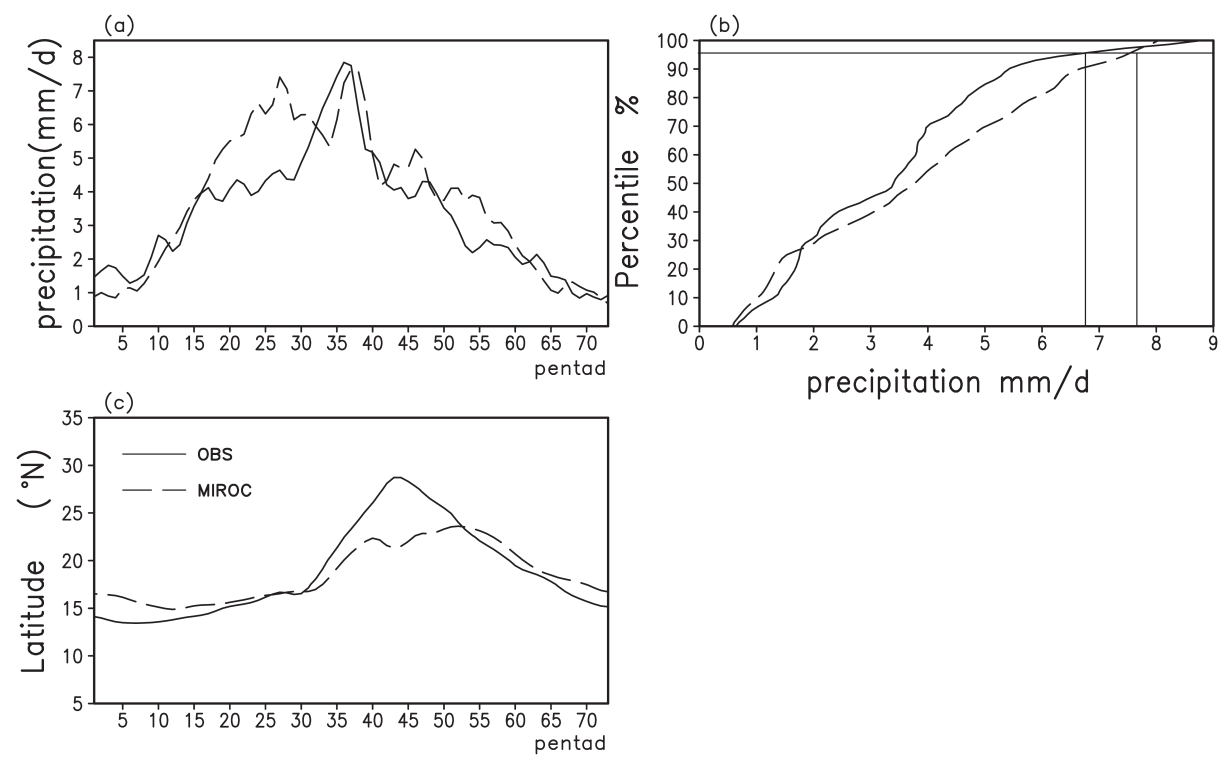

Fig. 1. (a) Seasonal evolution of area-averaged precipitation over the YHRB $\left(110^{\circ} \mathrm{E}-120^{\circ} \mathrm{E}, 28^{\circ} \mathrm{N}-34^{\circ} \mathrm{N}\right)$ (unit: $\mathrm{mm} \mathrm{d}^{-1}$ ) (b) Annual time series of area-averaged precipitation over YHRB is sorted in ascending order (unit: $\mathrm{mm} \mathrm{d}^{-1}$ ) (c) Latitudes of the WPSH ridge.
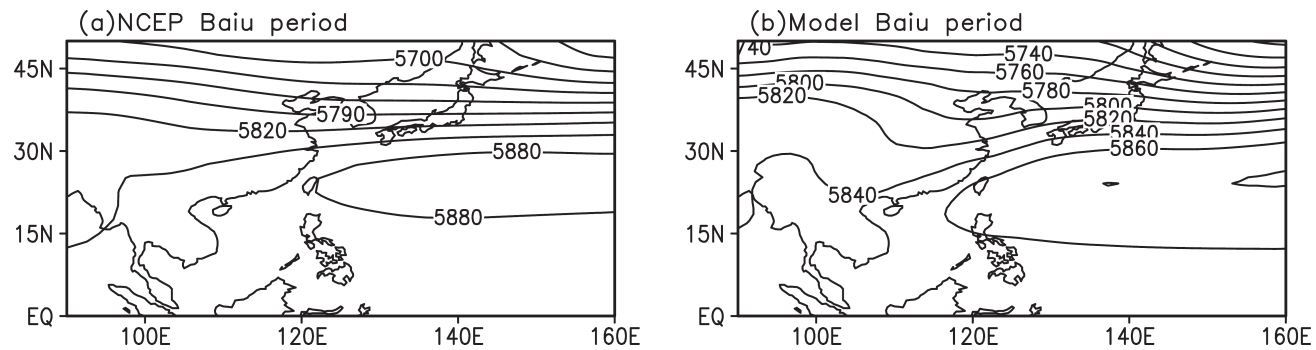

Fig. 2. The average height field at $500 \mathrm{hPa}$ during Baiu period (unit: degpm). (a) NCEP/NCAR reanalysis data (b) simulations Observation uses pentad 36-38 averages and simulation uses pentad 37-39 averages, same in Fig. 4-8.

et al. 2009). However, little attention has been paid on the AR4 simulations for studying the Baiu systems over YHRB.

In this study, we attempt to examine the simulated features of Baiu precipitation and 3-dimensional circulations during Baiu period over YHRB using an AR4 simulation with relatively high horizontal resolution. The aim of this paper is to answer the following questions:

(1) Can the model capture the Baiu period and the 3-dimensional circulation over YHRB in pentad scale?

(2) What is the key process for improving Baiu systems simulation?
The paper is structured as follows: Section 2 provides a brief description of the model and data. The detail definitions of Baiu period and Baiu precipitation are illustrated in Section 3. Section 4 addresses the horizontal and vertical features of Baiu circulations. Possible factors for improving the Baiu simulation are discussed in Section 5. Conclusions are in the final section.

\section{Data}

The coupled climate models used in this study have been developed jointly by the Atmosphere and Ocean Research Institute (AORI) of the University of Tokyo; National Institute for Environmental Studies (NIES); 
Table 1. The ISM index in NCEP/NCAR and simulations during the 25 th -35 th pentads, respectively. (The bold number means the changing point form negative to positive of ISM.)

\begin{tabular}{ccl}
\hline Time $($ Pentad) & NCEP/NCAR & \multicolumn{1}{c}{ Model } \\
\hline 25th pentad & -0.849849 & -0.94449 \\
26th pentad & -0.675024 & -0.65141 \\
27th pentad & -0.50451 & -0.6277 \\
28th pentad & -0.343944 & -0.44176 \\
29th pentad & -0.160419 & -0.15118 \\
30th pentad & $\mathbf{0 . 0 1 8 8 4 3 1}$ & -0.05339 \\
31th pentad & 0.43934 & $\mathbf{0 . 2 4 8 2 8 2}$ \\
32th pentad & 0.80879 & 0.591994 \\
33th pentad & 1.23505 & 0.567426 \\
34th pentad & 1.26225 & 0.806125 \\
35th pentad & 1.16719 & 0.835916 \\
\hline
\end{tabular}

and the Frontier Research Center for Global Change, Japan Agency for Marine-Earth Science and Technology (FRCGC/JAMSTEC) of Japan, called MIROC (Model for Interdisciplinary Research On Climate). Two versions of the model have been developed: a high-resolution version (MIROC_Hires) and a mediumresolution version (MIROC_Medres).

As pointed out by Kimoto et al. (2005), the higherresolution model better simulates mean and frequency distribution of precipitation in East Asian summer monsoon (EASM) region. Particularly, it is already known that T106 spectral truncation effectively captures both spatial and temporal characteristics of the East Asian monsoon (Sperber et al. 1994). Moreover, the MIROC_Hires shows relatively good performance in reproducing the circulation systems in East Asia, e.g., the frequency and intensity of precipitation (Sun et al. 2006; Zhu et al. 2009), the climatology structure of East Asian subtropical westerly jet (Zhang et al. 2008) and EASM (Min and Juhn 2010). Thus, the higher-resolution models could provide more credible results for projection of the Baiu systems than the lowerresolution models. In this study, we use high-resolution simulation (MIROC_Hires).

The MIROC_Hires has an atmospheric horizontal resolution of T106 spectral truncation $(\sim 100 \mathrm{~km}$ transform grid, $1.125^{\circ}$ (longitude) $\times 1.125^{\circ}$ (latitude) ) and 56 vertical levels with relatively finer vertical resolution in the planetary boundary layer and around the tropopause, $1 / 4^{\circ}$ (longitude) $\times 1 / 6^{\circ}$ (latitude) with 47 levels for the ocean and sea ice and a $0.5625^{\circ} \times 0.5625^{\circ}$ grid with 5

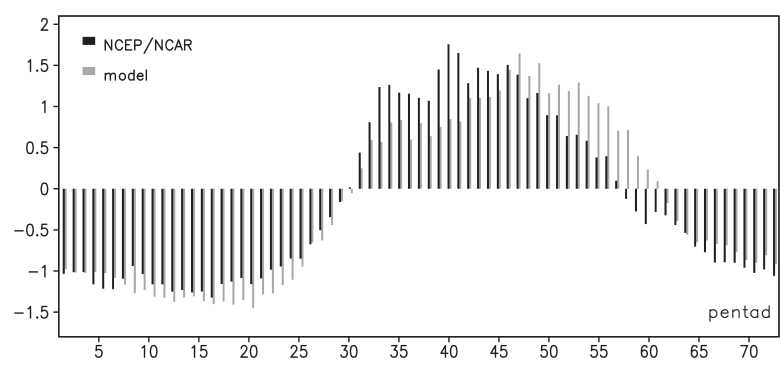

Fig. 3. Seasonal evolution of averaged ISM index during 1981-2000. (The time serial is measured in units of its respective standard deviation.)

soil layers for land. More details are described by the K-1 model developers (2004).

We use 20 year daily mean data for the present-day (1981-2000) for the 20th century climate simulations (20C3M) in IPCC AR4. The 20th century climate simulations are generated using various combinations of forcings, including greenhouse gases (GHGs), sulfate aerosols, ozone, volcanic aerosols and solar variability.

The National Centers for Environmental Prediction/National Center for Atmospheric Research (NCEP/NCAR) reanalysis data (Kalnay et al. 1996) for wind, temperature, vertical velocity and specific humidity from January 1981 to December 2000 is used to compare with the MIROC_Hires simulations. Moreover, the daily precipitation data within the period, 1981-2000, from the National Meteorological Information Center of China is used in this study. Although the simulation period is $1870-2000$, our study is mainly focused on the period 1981-2000, since reanalysis data are relatively reliable.

\section{Baiu precipitation distribution}

Three criteria are used to define Baiu period (Zhuo et al. 2010): (1) the ridge line of WPSH is steadily located at $20^{\circ} \mathrm{N}-25^{\circ} \mathrm{N}$; (2) the pentad mean precipitation amount over the YHRB exceeds the designated threshold value, the precipitation is ranked in ascending order, and the threshold value is defined as the 95th percentile of the sorted series; (3) the Baiu period exceeds continuous two pentads.

As shown in Fig. 1b, the precipitation threshold value of the observation and simulation is $6.8 \mathrm{~mm} \mathrm{~d}^{-1}$ and $7.5 \mathrm{~mm} \mathrm{~d}^{-1}$, respectively. In Fig. 1c, the WPSH ridge line in reanalysis data occurs steadily at $15^{\circ} \mathrm{N}$ from January to May, jumps northward apparently at the end of May, and then locates along $20^{\circ}-25^{\circ} \mathrm{N}$ from the middle 

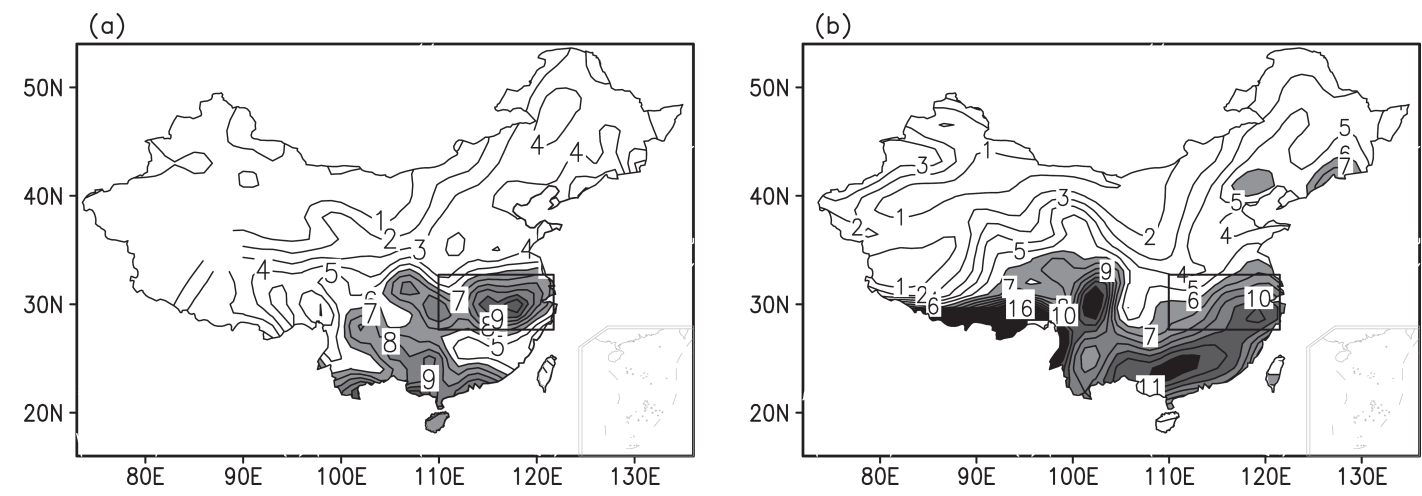

Fig. 4. Distribution of the mean precipitation during Baiu period (unit: $\mathrm{mm} \mathrm{d}^{-1}$ ). (a) observation (b) simulations Precipitation greater than $6 \mathrm{~mm} \mathrm{~d}^{-1}$ is shaded. The box indicates YHRB. The contour interval is $1 \mathrm{~mm} \mathrm{~d}^{-1}(\mathrm{a}$, b).

of June to the middle of July. The simulated ridge line begins to migrate northward nearly at the same time as in reanalysis data, and resides along $20^{\circ}-25^{\circ} \mathrm{N}$ from the middle of June to the end of August. Clearly, the simulated intensity of WPSH is weaker than NCEP/NCAR. As shown in Fig. 1a, the erroneous model peak in May (nearly the 25-30th pentad) is found in simulations, while the position of the simulated WPSH ridge line agrees with the observed position during this period. Thus, this simulated precipitation peak occurring in May is not Baiu period. In all, under the definition, the observed Baiu period is in the 36-38th pentads (from 25th June to 9th July) (Fig. 1a), which is in accordance with the results from previous research (Zhou 1996; Ding et al. 2007). In the simulation, the Baiu period is in the 37-39th pentad (from 30th June to 14th July), which is consistent with observation. However, the simulated Baiu period is one pentad later than the reanalysis data.

To examine the Baiu period, the geographical distribution of height at $500 \mathrm{hPa}$ during Baiu period is given in Fig. 2. Clearly, the model effectively reproduces the WPSH pattern. The WPSH ridge (5880 and 5860 line) is nearly along $22^{\circ} \mathrm{N}$ and $20^{\circ} \mathrm{N}$ in NCEP/NCAR reanalysis and simulations, respectively, which is accordance with the significant characteristics of the WPSH during the Baiu period mentioned in the second paragraph of the Introduction. This is also evidence for confirming the Baiu period. However, the simulated intensity of WPSH is weaker than NCEP/NCAR reanalysis data, which is in accordance with the results given from Fig. 1c. Therefore, the periods of the 36th-38th pentad and the 37 th-38th pentad can represent the Baiu period in observation and simulations, respectively.
It has been well documented that there is a close relationship between the position and features of Baiu and EASM (Ding 1992). In the EASM, the relationship between the Indian summer monsoon (ISM) and Baiu precipitation have been thoroughly studied (Ding 1999; Wu et al. 2000; Wang and LinHo 2002; Zhang et al. 2003). Suda and Asakura (1955) suggested that the onset of the ISM will lead the Baiu season. Recently, Liu and Ding (2008) indicated that the data concerning ISM onset over Kerala in the southwestern coast of the Indian Peninsula is about two weeks earlier than the beginning of the Meiyu over the YHRB. A dynamic index for the ISM is defined by Wang et al. (2001) using the difference in the $850 \mathrm{hPa}$ zonal winds between a southern region of $5^{\circ} \mathrm{N}-15^{\circ} \mathrm{N}, 40^{\circ} \mathrm{E}-80^{\circ} \mathrm{E}$ and a northern region of $20^{\circ} \mathrm{N}-30^{\circ} \mathrm{N}, 70^{\circ} \mathrm{E}-90^{\circ} \mathrm{E}$. The index changing from negative to positive indicates onset of the monsoon. The 25th-35th pentad ISM index is given in Table 1, apparently, the changing point is around the 30th and 31th pentad in NCEP/NCAR reanalysis and simulations. As shown in Fig. 3, the onset of Baiu period in simulation is one pentad later than the reanalysis data, which is also in good agreement with the difference in ISM period onset between simulations and reanalysis data. If the formations of simulated circulation systems (e.g., ISM, WPSH, low-level jet) delay, the onset and withdrawal of Baiu period will delay as well. This implies that the delay in ISM might be the cause of the delay of the Baiu period in the model.

Figure 4 shows the precipitation distribution during Baiu period for both the observation and simulations. In Fig. 4a, a heavy rainfall of $8-12 \mathrm{~mm} \mathrm{~d}^{-1}$ occurs over YHRB. The rain belt is mainly oriented from west to east along the mid-lower reaches of the YHRB, while 

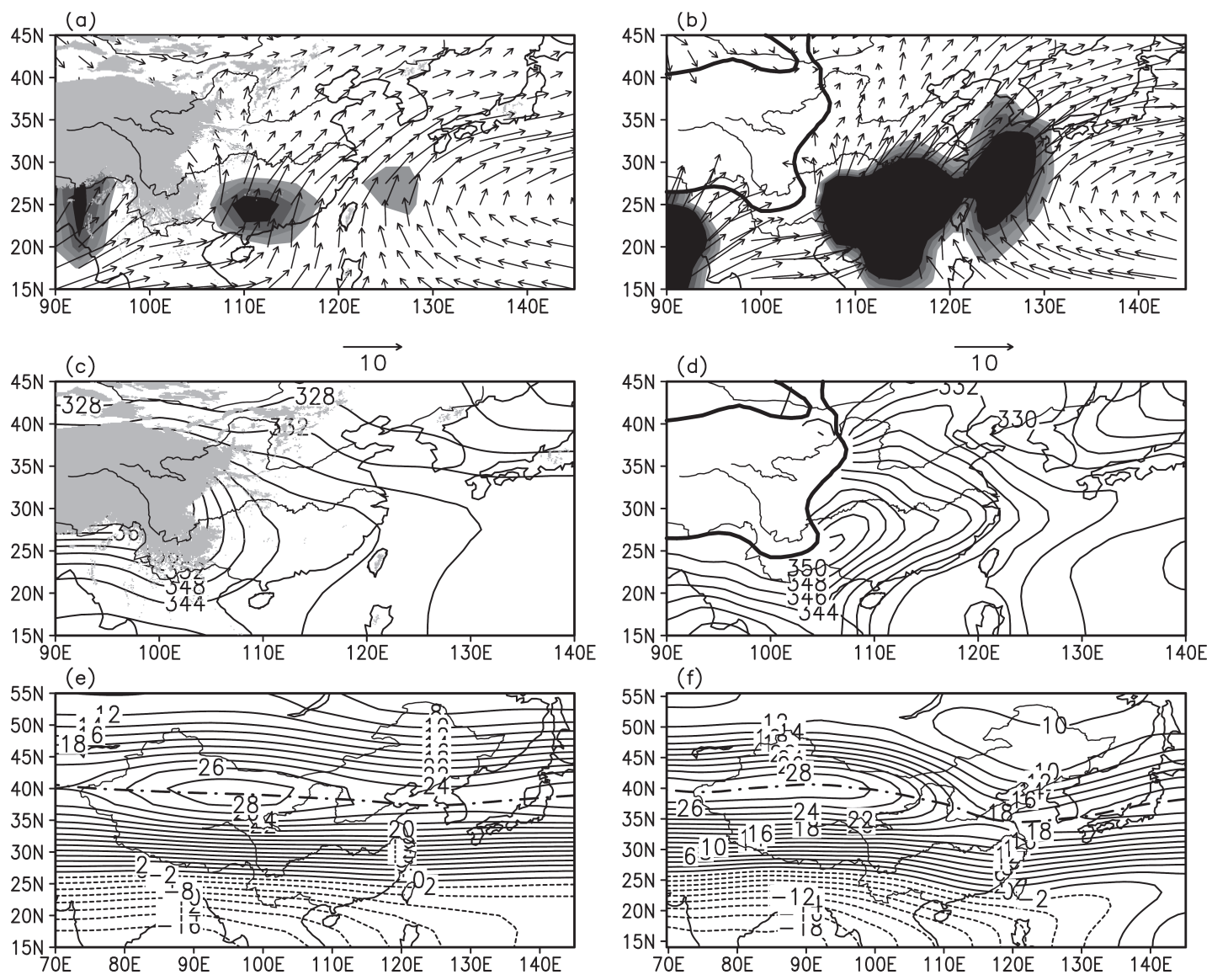

Fig. 5. During Baiu period, the fields of mean wind velocity (unit: $\mathrm{m} \mathrm{s}^{-1}$ ) (a, b), mean $\theta_{\mathrm{e}}$ (unit: $\mathrm{K}$ ) fields at $850 \mathrm{hPa}$ (c, d) and mean zonal winds (unit: $\mathrm{m} \mathrm{s}^{-1}$ ) at $200 \mathrm{hPa}(\mathrm{e}, \mathrm{f})$. (a, c, e) NCEP/NCAR reanalysis data, (b, d, f) simulations. The dark shaded regions $(a, b)$ are the meridional velocity above $5 \mathrm{~m} \mathrm{~s}^{-1}$. The bold solid line $(b, d)$ and the gray shaded regions in $(\mathrm{a}, \mathrm{c})$ indicate terrains above $1500 \mathrm{~m}$. The dash-dot line $(\mathrm{e}, \mathrm{f})$ is the westerly jet.

rainfall less than $6 \mathrm{~mm} \mathrm{~d}^{-1}$ occurs in southeastern China (Fig. 4a). Clearly, the model reproduces the maximum precipitation center located over YHRB (Fig. 4b). The spatial correlation between the simulation and observation is 0.54 over YHRB. However, there still exist obvious discrepancies, such as the overestimated precipitation in southeastern China.

\section{Associated circulation distributions}

It has been well documented that the Baiu is associated with the monsoon trough, the low level jet, the upper level jet, the WPSH and other large-scale atmosphere circulations (Saito 1966; Asakura 1971; Yoshino 1971; Akiyama 1973, 1975; Tao and Chen 1987). To clearly indicate the circulations during Baiu period, we choose a horizontal structure, such as the low-level jet illustrated by wind velocity at $850 \mathrm{hPa}$, the upper level jet described by zonal wind at $200 \mathrm{hPa}$, low-level moisture identified by $\theta_{\mathrm{e}}$ at $850 \mathrm{hPa}$, and a vertical structure containing $\theta_{\mathrm{e}}$, specific humidity and vertical velocity.

Figure 5 shows the wind velocity at $850 \mathrm{hPa}, \theta_{\mathrm{e}}$ at $850 \mathrm{hPa}$ and zonal winds at $200 \mathrm{hPa}$ for reanalysis data and simulations. At $850 \mathrm{hPa}$, a westerly from the Indo-China peninsula converging with the airflow on the southern flank of the WPSH reaches YHRB and Japan. The low-level winds show a considerable convergence zone over YHRB, which may be identified by the abrupt digression of strong southerlies along $30^{\circ} \mathrm{N}$ (Fig. 5a). In Fig. 5b, the simulated strong southwesterly wind along the rim of the west Pacific subtropical anticyclone is in good agreement with the reanalysis data. Whereas, the shaded regions (meridional wind larger than $5 \mathrm{~m} \mathrm{~s}^{-1}$ ) in simulations are larger than the reanalysis data, which means the intensity of the simulated low level jet is 

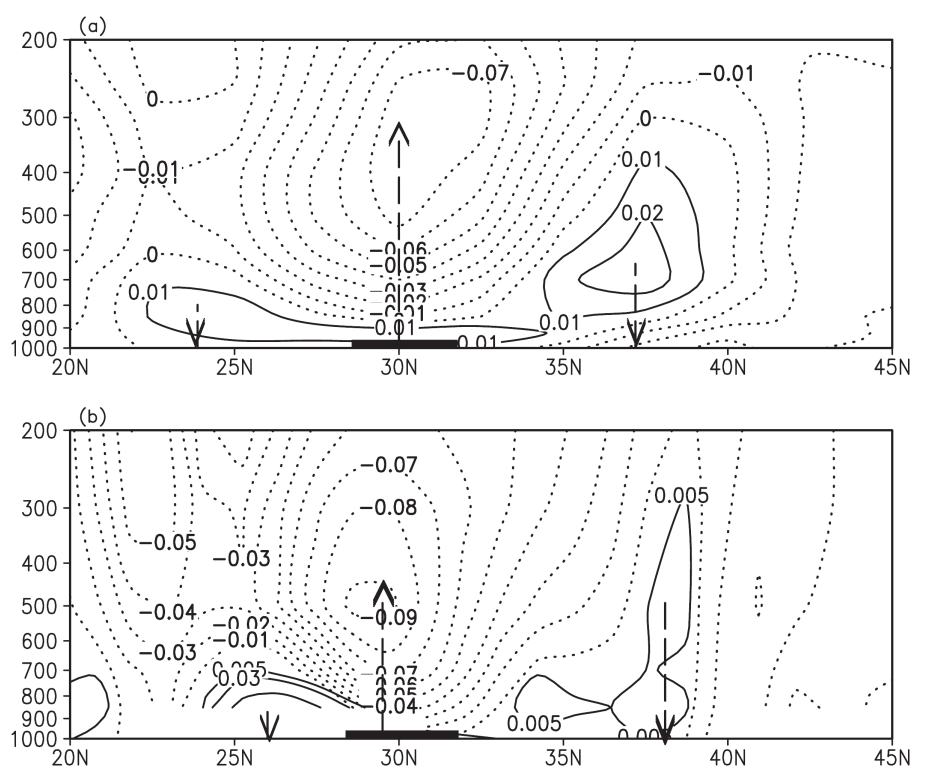

Fig. 6. Latitude-height cross sections of vertical velocity (unit: $\mathrm{Pa} \mathrm{s}^{-1}$ ) averaged from $110^{\circ} \mathrm{E}$ to $130^{\circ} \mathrm{E}$ (units: $\mathrm{Pa} \mathrm{s}^{-1}$ ). The vertical axis is height by pressure (a) NCEP/NCAR reanalysis data, (b) simulations. (The arrowhead means the direction of the movement.) The shaded area indicates the regions of YHRB.
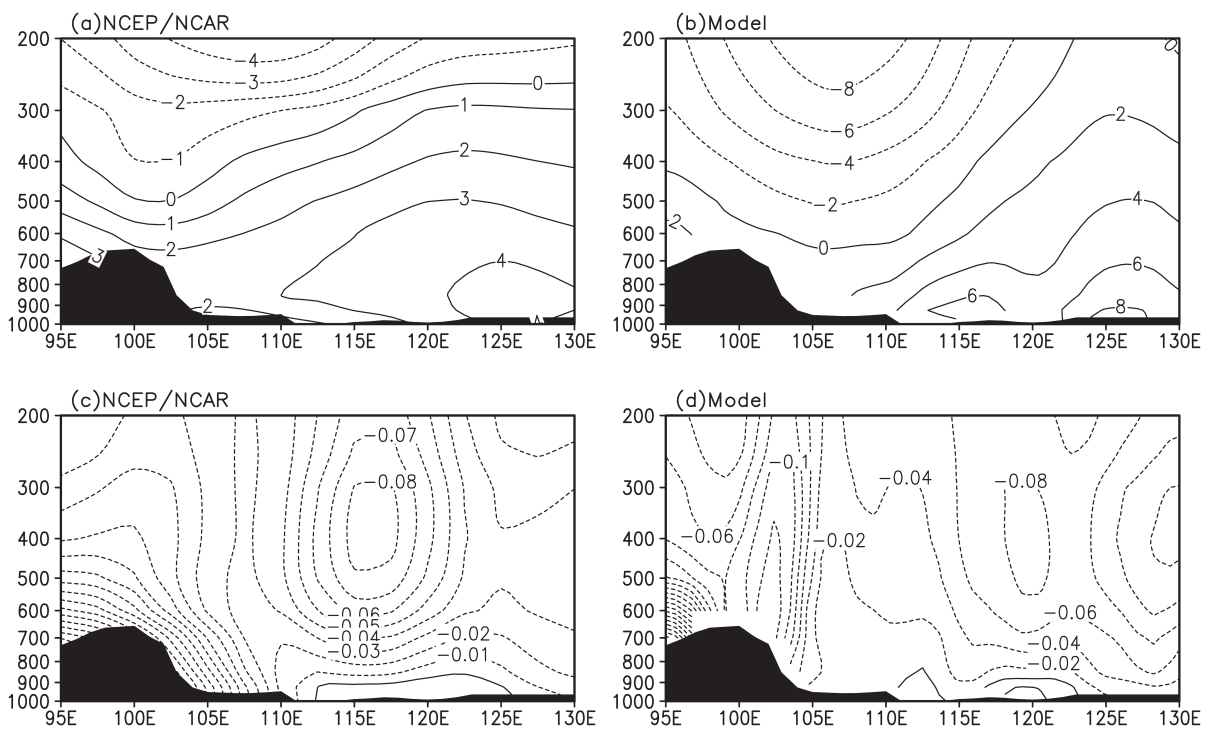

Fig. 7. Longitude-height cross sections of meridional winds averaged from $27.5^{\circ} \mathrm{N}$ to $32.5^{\circ} \mathrm{N}$ (unit: $\mathrm{m} \mathrm{s}^{-1}$ ) (a, b); Longitude-height cross section of the vertical velocity averaged from $27.5^{\circ} \mathrm{N}$ to $32.5^{\circ} \mathrm{N}$ (unit: $\mathrm{Pa} \mathrm{s}^{-1}$ ) (c, d). NCEP/NCAR reanalysis data $(a, c)$; simulations $(b, d)$.

stronger than reanalysis data. Since the strong southwesterly wind provides a lot of warm and humid air for Baiu precipitation, the intensity biases may result in bias related to simulated precipitation distribution.
The Baiu front is generally characterized by strong meridional gradients in moisture and the $\theta_{\mathrm{e}}$ wet tongue. As shown in Fig. 5c, a wet tongue extends from southwestern China to Japan at $850 \mathrm{hPa}$. An intensive $\theta_{\mathrm{e}}$ gra- 

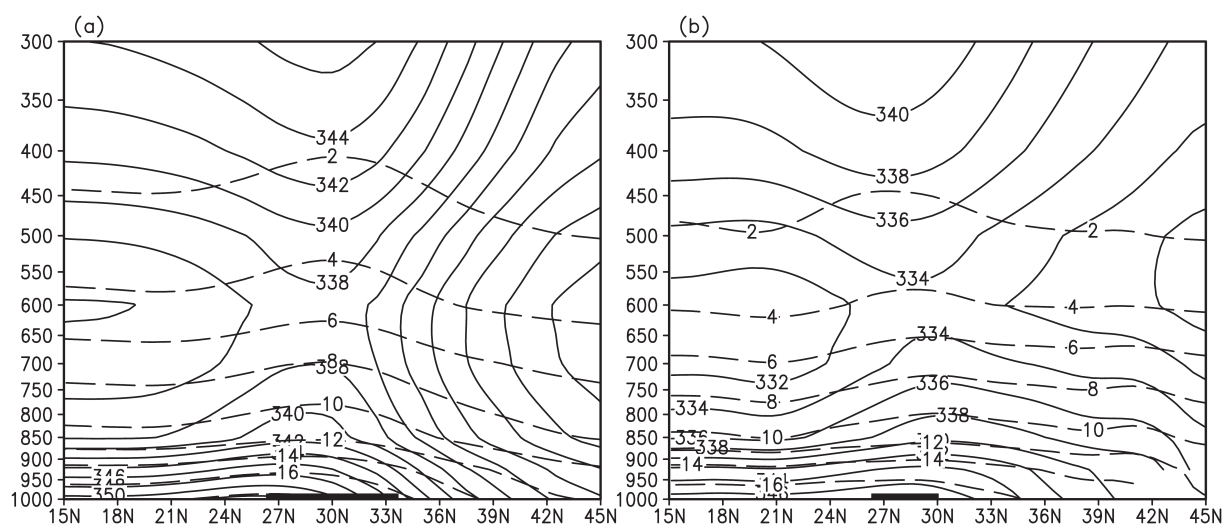

Fig. 8. Latitudinal-height cross sections of specific humidity (unit: $\times 10^{-3} \mathrm{~g} \mathrm{~kg}^{-1}$, dashed line) and $\theta_{\mathrm{e}}$ (unit: K, solid line). (a) reanalysis data, (b) simulations averaged from $110^{\circ} \mathrm{E}$ to $130^{\circ} \mathrm{E}$. The vertical axis is height by pressure (unit: $\mathrm{hPa}$ ). The black bar indicates the region of heavy precipitation.

dient belt is located over the northern side of YHRB and the humidity is discontinuous over heavy rain region (figure omitted). The model effectively simulates discrete humidity in the Baiu front zone. The $\theta_{\mathrm{e}}$ wet tongue and strong gradient zone at $850 \mathrm{hPa}$ are realistically reproduced over YHRB. However, the wet tongue is slightly stronger, and shifts northward in simulations (Fig. 5d).

Compared with the reanalysis data, the intensity of the westerly jet at $200 \mathrm{hPa}$ is well reproduced over the continent (Figs. 5e, f). However, it is underestimated over the ocean. Moreover, the jet clearly shifts southward, especially east of $110^{\circ}$ E. Zhang and Kuang (2006) examined the performance of a Chinese climate system model (FGCM0) in simulating the seasonal variation of East Asian subtropical westerly jets in the upper troposphere. The results indicated that the simulated unrealistically heavy precipitation center is related to the location and intensity biases in the subtropical westerly jet, which directly affect the maximum precipitation center during Baiu period (Du et al. 2008). Thus, the southward shift may be associated with positive anomalies in precipitation in southeastern China during Baiu period.

As shown in Fig. 6, the vertical structure of Baiu systems has been investigated by analyzing $\theta_{\mathrm{e}}$, specific humidity and vertical velocity. During Baiu period, the simulations indicate a strong ascending motion over the heavy precipitation area (along $28^{\circ}-30^{\circ} \mathrm{N}$ ) and compensatory descending motions are found over the northern and southern sides along the heavy precipitation belt. In all, the upward and downward motions are in good agreement with the reanalysis data.

As shown in Fig. 7, meridional and vertical winds averaged from $27.5^{\circ} \mathrm{N}$ to $32.5^{\circ} \mathrm{N}$ within the simulations are in accordance with reanalysis data, especially from $110^{\circ} \mathrm{E}$ to $130^{\circ} \mathrm{E}$. Consequently, the Baiu precipitation is well simulated over YHRB. However, over the Tibetan region (shaded area), the meridional and vertical winds in simulations are stronger than in the reanalysis data, which may be associated with the unrealistic precipitation simulated in the eastern area of Tibetan Plateau. This is probably related to the inappropriately resolved topography of Tibetan Plateau in the model (Qian and Shen 1990; Qian 2000; Zhang et al. 2006).

Figure 8 shows the latitudinal-vertical profile of $\theta_{\mathrm{e}}$ and specific humidity averaged from $110^{\circ} \mathrm{E}$ to $130^{\circ} \mathrm{E}$. In reanalysis data (Fig. 8a), the large $\theta_{\mathrm{e}}$ gradient belt extends from surface to $600 \mathrm{hPa}$ over the northern side of heavy rainfall area, and a high moist air column is found to the south of the large $\theta_{\mathrm{e}}$ gradient belt. As shown in Fig. $8 \mathrm{~b}$, the model effectively reproduces the $\theta_{\mathrm{e}}$ distribution with high value in the lower layer, especially along the heavy rainfall zone and the relatively low value in the middle layer. In the simulations, the meridional $\theta_{\mathrm{e}}$ gradient is large in the Baiu rain belt and slightly weakens to the south in the middle and lower troposphere. Moreover, the model basically reproduces the characteristics of a quasi symmetric saddle type of $\theta_{\mathrm{e}}$.

From the analysis mentioned above, it is obvious that MIROC_Hires accurately reproduces the major features of Baiu period, precipitation and its associated circulations. The obvious discrepancies in the simulations are a southward shift of the subtropical westerly jet 

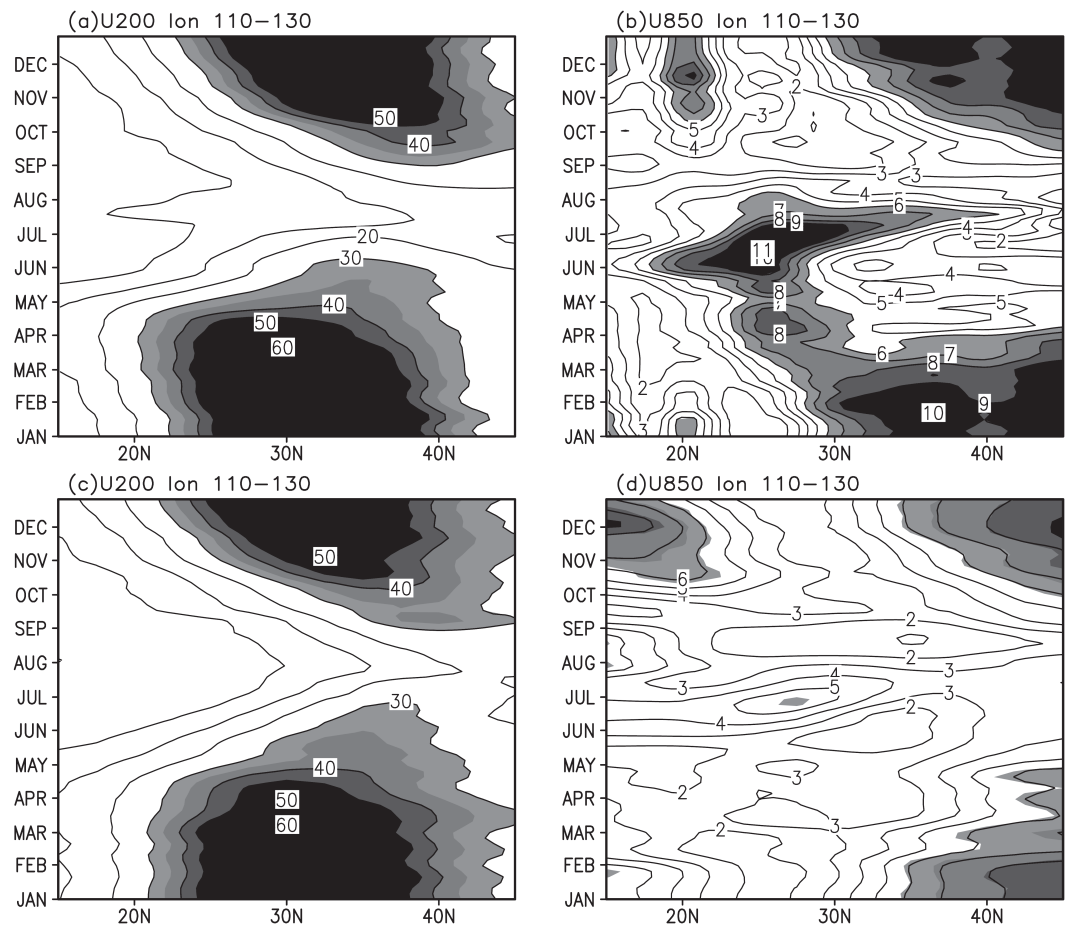

Fig. 9. The latitude-temporal variation of zonal winds at $200 \mathrm{hPa}(\mathrm{a}, \mathrm{c})$ and at $850 \mathrm{hPa}(\mathrm{b}$, d) averaged between $110^{\circ} \mathrm{E}-130^{\circ} \mathrm{E}$ in simulations $(\mathrm{a}, \mathrm{b})$ and NCEP/NCAR reanalysis data (c, d) (unit: $\mathrm{m} \mathrm{s}^{-1}$ ). The values above $30 \mathrm{~m} \mathrm{~s}^{-1}(\mathrm{a}, \mathrm{c})$ and $6 \mathrm{~m} \mathrm{~s}^{-1}(\mathrm{~b}, \mathrm{~d})$ are shaded. The contour interval is $10 \mathrm{~m} \mathrm{~s}^{-1}(\mathrm{a}, \mathrm{c})$ and $2 \mathrm{~m} \mathrm{~s}^{-1}(\mathrm{~b}, \mathrm{~d})$, respectively.

and overestimated southwesterly winds from the IndoChina peninsula.

\section{Discussion}

Obvious discrepancies are revealed between the simulations and NCEP/NCAR reanalysis data on the features of Baiu systems, indicating the model overestimates the Baiu precipitation in southeastern China. In this section, we try to find possible reasons for the discrepancies by analyzing the coupled structure of the upper and lower level jet.

Several previous studies have related the Baiu to the lower and upper level jets (e.g., Simmonds et al. 1999; Zhou and Yu 2005; Zhang and Kuang 2006; Ding et al. 2007; Du et al. 2008; Liu and Ding 2008; Zhang and Kuang 2008). Du et al. (2008) found that the changes in the location and intensity of the westerly jet were not only associated with the start and end of Baiu period, but also associated with the spatial distribution and intensity of Baiu precipitation in YHRB. Based on observational analysis, Zhang and Kuang (2008) indicated the south-north location of the westerly jet impact the variation within the rain belt during the Baiu period through the East Asian summer monsoon. Liu and Ding (2008) and Ding et al. (2007) mentioned the intensity of the lower level jet as associated with the ascending motion and transport of water vapor. Moreover, the coupled structure of the upper and lower level jet is one of the important circulations beneficial to strong precipitation occurring over YHRB during Baiu period (Zhou and Yu 2005; Zhang and Kuang 2006). As mentioned in Section 4, the wind bias between simulations and reanalysis data is largest in the Baiu systems. Thus, the main cause of the model biases in Baiu precipitation may be the unrealistic meandering within the upper-level subtropical jet and the intensity of the lower-level jet. Figure 9 shows the evolution of the upper and lower level jet. Clearly, in regards to the latitude-time variation of the upper level jet, the seasonal structure is well simulated in cold season (September-December). However, during Baiu period, the model underestimates the intensity of the upper level jet and cannot reproduce the northern tilting structure. In the simulations, the intensity of the upper level jet arrives at maximum along $30^{\circ} \mathrm{N}$, while 
in reanalysis data, it occurs around $40^{\circ} \mathrm{N}$. On the evolution of the lower level jet, the model overestimates the intensity of the lower level jet, especially during Baiu period. Furthermore, the model simulates a larger center within the lower level jet located over the southern part of China during Baiu period. In this study, we find the location of the simulated upper level jet shifts southward, which will result in the southward movement of the rain belt during Baiu period. The model overestimates the intensity of the lower level jet, which benefits bringing sufficient water vapor to southeastern China. Thus, the configuration between the upper and lower level jets (e.g., southward shifting of the upper level jet and the stronger lower level jet in southeastern China) simulated by the models benefits rainfall over southeastern China, which is one of the possible reasons for overestimation of Baiu precipitation in southeastern China.

\section{Conclusions}

In this study, the performance of AORI/NIES/FRCGC coupled climate system model in simulating Baiu systems is evaluated. The main conclusions are as follows:

(1) The climatic Baiu period is the 36-38th and 3739th pentads in reanalysis data and simulations, respectively. The simulated onset of Baiu period tends to delay by about one pentad compared with that of observation. Similarly, the simulated onset of ISM tends to delay by about one pentad compared with that of observation. In the model, the delay of ISM might be the cause for delay in Baiu period.

(2) During the Baiu period, the model has good performance in simulating the Baiu precipitation distribution, especially over YHRB. However, the model overestimates the Baiu precipitation over southeastern China. The simulated horizontal and vertical circulations associated with Baiu systems are in good agreement with reanalysis data. However, the simulated westerly jet shifts southward and the intensity of low level jet is stronger than reanalysis data.

(3) The southward shifting of the upper level jet affected the southward movement of the rain belt during Baiu period. The simulated stronger lower level jet brings sufficient water vapor to southeastern China.

(4) Under the described configuration of the upper and lower level jets, the simulated larger Baiu precipitation center locates over southern China, which results in the bias of Baiu precipitation between simulations and reanalysis data. In all, the variation of ISM and the configuration of upper and lower level jet may be one of the key processes in the MIROC_Hires model to be improved for the simulation of Baiu.

This study only focuses on the climatological Baiu period and associated circulations. The atmospheric dynamic processes also need to be studied in following research. Because of the model dependence, the performance of the other models participating IPCC AR4 in simulating Baiu precipitation and its associated circulations need to be evaluated in the future.

\section{Acknowledgements}

We thank the editor and two anonymous reviewers for their valuable comments and suggestions. Thanks to Professor Masaaki Takahashi for the Japanese abstract. The NCEP/NCAR reanalysis data was provided by the National Centers for Environmental Prediction (NCEP) and National Center for Atmospheric Research (NCAR). This study is supported by the National Natural Science Foundation of China (Grant Nos. 41105044 and 41130963), the National Basic Research Program of China (973 Program; Grant No. 2011CB952002), the Open Project Program of Key Laboratory of Meteorological Disaster of Ministry of Education (Nanjing University of Information Science and Technology) (Grant No. KLME1105), Fundamental Research Funds for the Central Universities (Grant No. 1107020730 and 1084020702), and the Research Fund for the Doctoral Program of Higher Education (Grant No. 20100091110003). This work was completed when the first author was on leave for a visit at the Center for Climate System Research (now is called Atmosphere and Ocean Research Institute), University of Tokyo.

\section{References}

Asakura, T., 1971: Distribution and variation of cloudiness and precipitable water during the rainy season over monsoon Asia. Water Balance of Monsoon Asia, M. M. Yoshino, Eds., University of Tokyo Press, 131-151.

Akiyama, T., 1973: The large-scale aspects of the characteristic features of the Baiu front. Pap. Meteor. Geophys., 24, 157-188.

Akiyama, T., 1975: Southerly transversal moisture flux into the extremely heavy rainfall zone in the Baiu season. $J$. Meteor. Soc. Japan, 53, 304-316.

Chen, T. J. G., and C. P. Chang, 1980: The structure and vorticity budget of an early summer monsoon trough 
("Mei-Yu") over southeastern China and Japan. Mon. Wea. Rev., 108, 942-953.

Ding, Y. H., 1992: Summer Monsoon Rainfalls in China. $J$. Meteor. Soc. Japan, 70, 373-396.

Ding, Y. H., and C. Y. Li, 1999: Evolution of the South China Sea Monsoon and its interaction with the ocean. Beijing: Meteorological Press, 1-4. (in Chinese)

Ding, Y. H., J. J. Liu, and Y. Sun, 2007: A study of the synoptic-climatology of the Meiyu system in East Asia. Chinese J. Atmos. Sci., 31, 1082-1101. (in Chinese)

Du, Y., Y. C. Zhang, and Z. Q. Xie, 2008: Impacts of longitude location changes of East Asian westerly jet core on the precipitation distribution during Meiyu period in middle lower reaches of Yangtze River valley. Acta Meteorologica Sinica, 66, 566-576.

Guo, L. L., Y. C. Zhang, B. Wang, et al., 2008: Simulations of the East Asian subtropical westerly jet by LASG/IAP AGCMs. Adv. Atmos. Sci., 25, 447-457.

Hu, Y. M., and Y. H. Ding, 2010: Simulation of 19912005 Meiyu seasons in the Yangtze-Huaihe region using BCC_RegCM 1.0. Chinese Sci. Bull., 55, 10771083, doi:10.1007/s11434-009-0473-z.

Huang, R. H., Z. Zhang, and G. Huang, 1998: Characteristics of the water vapor transport in east Asian monsoon region and its difference from that in south Asian monsoon region in summer. Sci. Atmos. Sinica, 22, 460469. (in Chinese)

K-1 model developers, 2004: K-1 coupled GCM (MIROC) description. $K-1$ technical report, Hasumi, H., and S. Emori, Eds., Center for Climate System Research, University of Tokyo, $34 \mathrm{pp}$.

Kalnay, E., M. Kanamitsu, and R. Kistler, et al., 1996: The NCEP/NCAR 40-year Reanalysis Project. Bull. Amer. Meteor. Soc., 77, 437-472.

Kar, S. C., M. Sugi, and N. Sato, 1996: Simulation of the Indian summer monsoon and its variability using the JMA global model. Pap. Meteor. Geophys., 47, 65101.

Kawatani, Y., and M. Takahashi, 2003: Simulation of the Baiu front in a high resolution AGCM. J. Meteor. Soc. Japan, 81, 113-126.

Kimoto, M., 2005: Simulated change of the east Asian circulation under the global warming scenario. Geophys. Res. Lett., 32, L16701, doi:10.1029/2005GL023383.

Kitoh, A., and T. Uchiyama, 2006: Changes in onset and withdrawal of the East Asian summer rainy season by multi-model global warming experiments. J. Meteor. Soc. Japan, 84, 247-258.

Lau, K. M., G. J. Yang, and S. H. Shen, 1988: Seasonal and intraseasonal climatology of summer monsoon rainfall over East Asia. Mon. Wea. Rev., 116, 18-37.

Li, H. M., A. G. Dai, and T. J. Zhou, et al., 2008: Responses of East Asian summer monsoon to historical SST and atmospheric forcing during 1950-2000. Climate Dyn., doi:10.1007/s00382-008-0482-7.
Liu, Y. Y., and Y. H. Ding, 2008: Teleconnection between the Indian summer monsoon onset and the Meiyu over the Yangtze River Valley. Science in China Series D: Earth Sciences, 5, 1021-1035.

Matsumoto, S., K. Ninomiya, and S. Yoshizaki, 1971: Characteristics of the Baiu front with heavy rainfall. $J$. Atmos. Sci., 21, 361-385.

Meehl, G. A., C. Covey, M. Latif, et al., 2004: Soliciting participation in the climate model analyses leading to the IPCC Fourth Assessment Report. Eos, Trans. Am. Geophys. Union, 29, 274.

Meehl, G. A., C. Covey, B. McAvaney, et al., 2005: Overview of the Coupled Model Intercomparison Project. Bull. Amer. Meteor. Soc., 86, 89-93.

Min, H. J., and J. G. Jhun, 2010: The changes in the East Asian summer monsoon simulated by the MIROC3.2 high-resolution coupled model under Global warming scenarios. Asia-Pacific J. Atmos. Sci., 45, 73-88.

Ninomiya, K., 1984: Characteristics of Baiu front as a predominant subtropical front in the summer Northern Hemisphere. J. Meteor. Soc. Japan, 62, 880-894.

Ninomiya, K., T. Suzuki, and T. Nishimura, 2008: Differences between the intense precipitation associated with subsynoptic-scale Baiu frontal depression simulated by an AGCM and described in observational studies. $J$. Meteor. Soc. Japan, 86, 563-573.

Ninomiya, K., 2009: Characteristics of precipitation in the Meiyu-Baiu season in the CMIP3 20th century climate simulations. J. Meteor. Soc. Japan, 87, 829-843.

Qian, Y., and J. Shen, 1990: Effects of Tibetan plateau on short-range numerical weather prediction. Scientia Meteor Sinica, 10,129-10,138. (in Chinese)

Qian, Y., 2000: Effects of the envelope orography and gravity wave drag on climate modeling. Quart. J. Appl. Meteor., 11, 13-20. (in Chinese)

Saito, N., 1966: A preliminary study of the summer monsoon of southern and eastern Asia. J. Meteor. Soc. Japan, 44, 44-59.

Sperber, K. R., S. Hameed, G. L. Potter, et al., 1994: Simulation of the northern summer monsoon in the ECMWF model: Sensitivity to horizontal resolution. Mon. Wea. Rev., 122, 2461-2481.

Simmonds, I., D. Bi, and P. Hope, 1999: Atmospheric water vapor flux and it $\mathrm{s}$ association with rainfall over China in summer. J. Climate, 12, 1353-1367.

Suda, K., and T. Asakura, 1955: A study on the unusual "Baiu" season in 1954 by mean of northern hemisphere upper air mean charts. J. Meteor. Soc. Japan, 33, 233 244.

Sugi, M., R. Kawamura, and N. Sato, 1995: The climate simulated by the global model. Part 1: Global features. Report of the National Research Institute for Earth Sciences and Disaster Prevention, 54, 155-180.

Sun, Y., S. Solomon, A. G. Dai, et al., 2006: How often does it rain? J. Climate, 19, 916-934.

Tao, S. Y., and L. X. Chen, 1987: A review of recent re- 
search on the East Asian summer monsoon in China. Reviews in Monsoon Meteorology, C.-P. Chang and $\mathrm{Kr}-$ ishnamurti, Eds., Oxford University Press, 60-92.

Wang, B., and H. LinHo, 2002: Rainy season of the AsianPacific summer monsoon. J. Climate, 15, 386-398.

Wang, B., R. G. Wu, and K. M. Lau, 2001: Interannual variability of the Asian Summer Monsoon: Contrasts between the Indian and the Western North Pacific-East Asian Monsoons. J. Climate, 14, 4073-4090.

Wu, G. X., P. Liu, Y. M. Liu, et al., 2000: Impacts of the sea surface temperature anomaly in the Indian ocean on the subtropical anticyclone over the western Pacifictwo-stage thermal adaptation in the atmosphere. Acta Meteor. Sinica, 58, 513-522. (in Chinese)

Yoshino, M. M., 1971: Water balance problems in monsoon Asia from the view point of climatology. Water Balance of Monsoon Asia, M. M. Yoshino, Eds., University of Tokyo Press, 2-234.

Zhang, Q., P. Liu, and X. G. Wu, 2003: The relationship between the flood and drought over the lower reach of the Yangtze River Valley and the SST over the Indian Ocean and the South China Sea. Chinese J. Atmos. Sci., 27, 992-1006. (in Chinese)

Zhang, Y. C., M. Takahashi, and L. L. Guo, 2008: analysis of the East Asian subtropical westerly jet simulated by CCSR/NIES/FRCGC coupled climate system model. J. Meteor. Soc. Japan, 86, 257-278.

Zhang, Y. C., A. N. Huang, and X. S. Zhu, 2006: Parameterization of the thermal impacts of sub-grid orography on numerical modeling of the surface energy budget over East Asia. Theoretical and Applied Climatology, 86, 201-214, doi:10.1007/s00704-005-0209-1.

Zhang, Y. C., and X. Y. Kuang, 2006: Simulation of Seasonal Variation of the East Asian Subtropical Westerly
Jet in a Coupled Climate System Model FGCM0. Chinese J. Atmos. Sci., 30, 1177-1188. (in Chinese)

Zhang, Y. C., and X. Y. Kuang, 2008: The relationship between the location change of the East Asian summer westerly jet and Asian summer monsoon onset. Torrential Rain and Disasters, 27, 97-103. (in Chinese)

Zhou, T. J., and R. C. Yu, 2005: Atmospheric water vapor transport associated with typical anomalous summer rainfall patterns in China. J. Geophys. Res., 110, D08104, doi:10.1029/2004JD005413.

Zhou, T. J., and R. C. Yu, 2006: Twentieth century surface air temperature over China and the Global simulated by coupled climate models. J. Climate, 19, 5843-5858.

Zhou, T. J., R. C. Yu, H. M. Li, et al., 2008: Ocean forcing to changes in global monsoon precipitation over the recent half-century. J. Climate, 21, 3833-3852.

Zhou, T. J., R. C. Yu, and J. Zhang, et al., 2009: Why the Western Pacific subtropical high has extended westward since the Late 1970s. J. Climate, 22, 2199-2215.

Zhou, Z. K., 1996: Meiyu rainfall in Janghuai zonal. China Meteorological Press, 10-14. (in Chinese)

Zhu, J., Y. C. Zhang, and D. Q. Huang, 2009: Analysis of Changes in Different-Class Precipitation over Eastern China under Global Warming. Plateau Meteorology, 28, 889-896. (in Chinese)

Zhu, Q. G., L. J. Rui, S. W. Shou, et al., 2000: The principle and method of synoptic meteorology (The third edition), 350-360. (in Chinese)

Zhuo, D. Q., Y. C. Zhang, B. Wang, et al., 2010: An Analysis of the Meiyu Precipitation and Associated Circulations Simulated by the Grid-Point Atmospheric Model of IAP LASG (GAMIL). Acta Meteor. Sinica, 24, 328339. 